\title{
Boron Removal from Aqueous Solutions by Strong Base Anion-exchange Resin Batch and Column Experiments
}

\author{
György Pátzay ${ }^{1 *}$, József Dobor'1, Emil Csonka², Gábor Lozsi³, Ferenc Feil ${ }^{3}$ \\ 1 Department of Industrial Safety, Institute of Disaster Management, Faculty of Law Enforcement, National University of Public \\ Service, Ludovika tér 2, H-1083 Budapest, Hungary \\ 2 Department of Chemical and Environmental Process Engineering, Faculty of Chemical Technology and Biotechnology, Budapest \\ University of Technology and Economics, Műegyetem rkp. 3., H-1111 Budapest, Hungary \\ ${ }^{3}$ MVM Paks Nuclear Power Plant Ltd., P. O. B. 71, H-7031 Paks, Hungary \\ *Corresponding author, e-mail: gypatzay@mail.bme.hu
}

Received: 07 September 2020, Accepted: 12 October 2020, Published online: 22 March 2021

\begin{abstract}
Borate ion exchange capacity of Purolite NRW600 strong base anion resin in hydroxide form and mixed bed NRW600+NRW100 ion exchange was investigated with static experiments. Anion exchange resin was saturated with $0.1-45 \mathrm{~g} / \mathrm{dm}^{3}$ concentration boric acid solution in a static mixer at $20,30,40$ and $50^{\circ} \mathrm{C}$ at $150 \mathrm{rpm}$ for 24 hours. Remaining borate content of saturation solutions was determined with ion chromatography and ICP-OES. The amount of fixed borate as borate anions increased with the saturation borate concentration as well as in case of simple anion exchange as in case of mixed bed.

Column sorption-elution study was carried out by using strong base anion exchange resins (Purolite NRW600 and Amberlite IRN78). Resins in hydroxide and in chloride forms were saturated in column with 5-40 g/ $\mathrm{dm}^{3}$ boric acid solution in excess. The resin was then eluted with $200 \mathrm{~cm}^{3}$ salt free water with $5 \mathrm{~cm}^{3} / \mathrm{min}$ at $25{ }^{\circ} \mathrm{C}$ and then eluted by $1 \mathrm{~mol} / \mathrm{dm}^{3}$ sodium-sulfate solution with $5 \mathrm{~cm} / \mathrm{min}$. The effluent was collected and analyzed for borate content by titrimetric method. In chloride form the resin adsorbed and released much less borate. Effective borate and polyborate sorption needs hydroxide ions in resin phase.
\end{abstract}

Keywords

borate, anion exchange, polyborates, apparent capacity, water elution

\section{Introduction}

Boron as the soluble boric acid is used as a neutron absorbent in the primary circuit of PWR NPP (Pressurized Water Reactor Nuclear Power Plant) to control the neutron flux. Adjusting the boron concentration in the coolant provides compensation for reactor reactivity and control of power generation $[1,2]$. It assures reactor safety during reactor startup, power changes, shutdown, as well as refueling and maintenance operations.

The ion exchange resins may be used in PWR in separate anion and cation beds or in mixed beds. The anion resins are usually borate saturated and the boric acid in the waste stream passes through with little change. Most of the ionic radionuclides in the waste stream can be removed and retained on the resins.

The Paks NPP in Hungary consists of four units with WWER-440/213. Paks 1-4 has several separate systems for the treatment and storage of aqueous radioactive streams and wastes. One of these systems is intended for decontamination, concentration, purification, storage, and recovery of boric acid from coolant water discharged from the primary circuit (reactor let-down). The ion exchange purification systems (unit No. 2, 4 and 6) are used to separate and polish some streams containing boric acid with different concentrations. Units contain cation and anion exchange columns with 1.5 and $2.8 \mathrm{~m}^{3}$ of ion exchangers in hydrogen, hydroxide, and borate forms. During the regeneration steps large amount of radioactive boric acid solutions are generated and should be treated with the liquid radioactive waste water treatment system.

The chemistry of a boron aqueous solution is characterized by the existence of a series of polyborate anionic species along with boric acid and monomeric borates, and by the fact that boric acid undergoes hydration before ionization. The formation of different borate groups and their structures depends on $\mathrm{pH}$, temperature, and boron concentration. At the acidic and basic extremes of $\mathrm{pH}$, 
the primary species in solution are $\mathrm{B}(\mathrm{OH})_{3}$ and the mononuclear borate ion $\left(\mathrm{B}(\mathrm{OH})_{4}\right)$. In a dilute boric acid solution (less than $0.025 \mathrm{M}$ ), essentially only mononuclear species $\mathrm{B}(\mathrm{OH})_{3}$ and $\mathrm{B}(\mathrm{OH})_{4-}$; are present. As boron concentration increases or temperature decreases, the possibility of forming polynuclear borates increases. There is no unanimous agreement about the structures and forms of polyborates.

The determination of concentration distribution of boric acid and borates is based on the postulation proposed by Mesmer and his co-workers [3, 4]. Figs. 1-3 show these

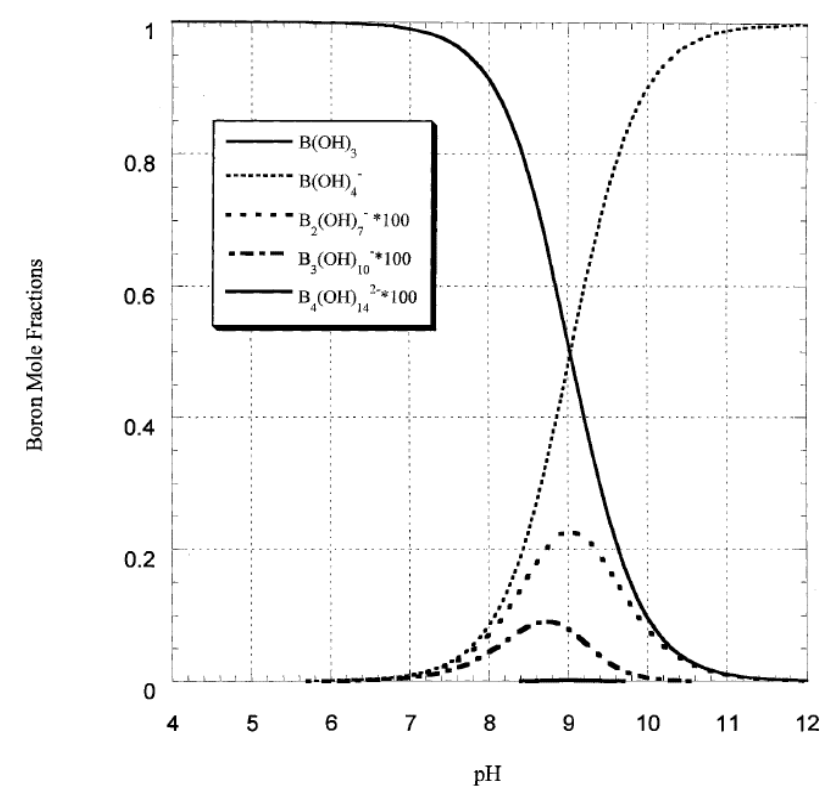

Fig. 1 Distribution of boron forms in aqueous solution at boron concentration $100 \mathrm{ppm}$ and temperature $10^{\circ} \mathrm{C}$ as a function of $\mathrm{pH}$ [5]

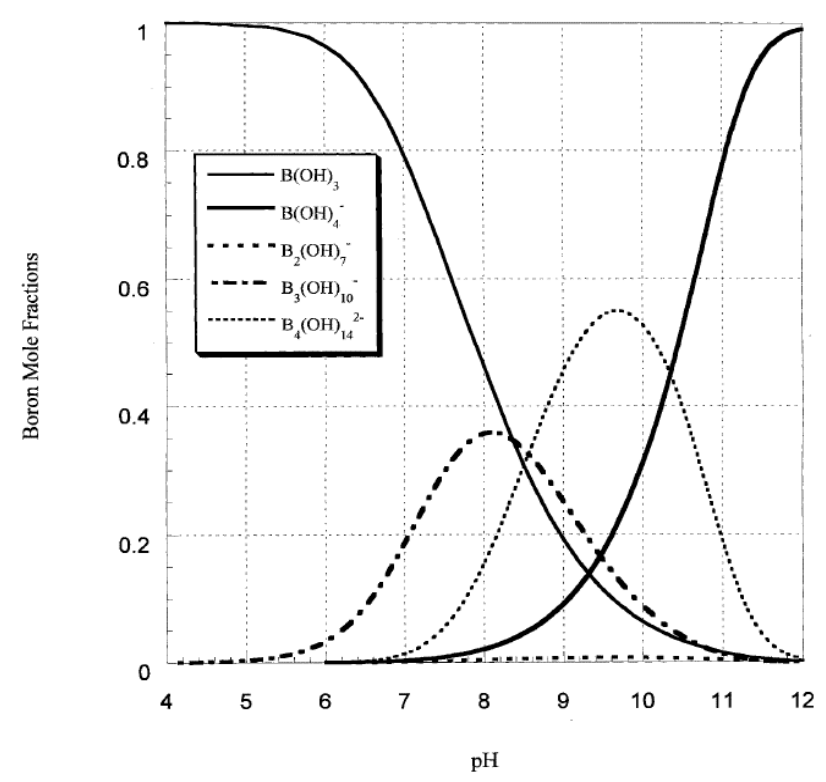

Fig. 2 Distribution of boron forms in aqueous solution at boron concentration $6500 \mathrm{ppm}$ and temperature $10^{\circ} \mathrm{C}$ as a function of $\mathrm{pH}$ [5]

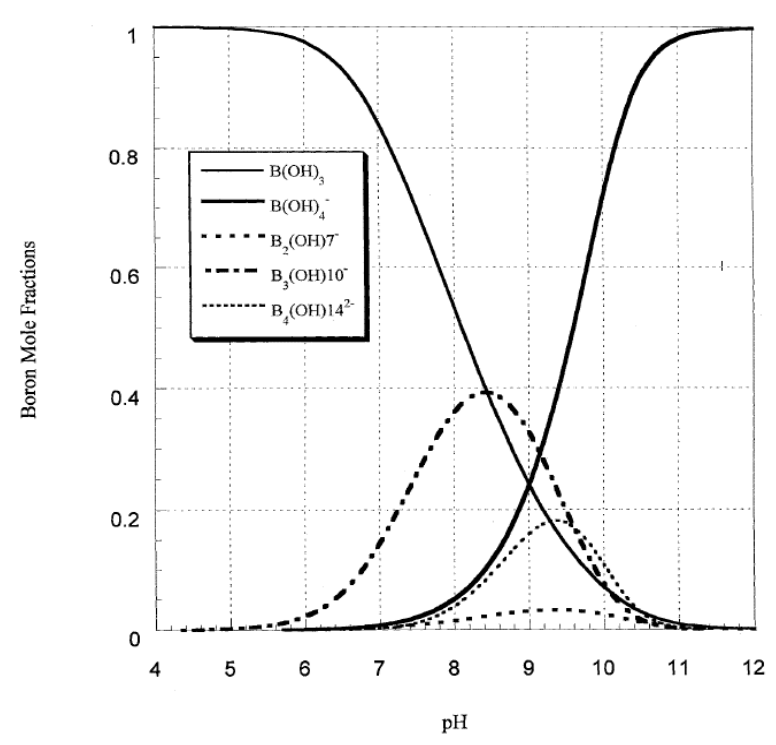

Fig. 3 Distribution of boron forms in aqueous solution at boron concentration $6500 \mathrm{ppm}$ and temperature $60^{\circ} \mathrm{C}$ as a function of $\mathrm{pH}$ [5]

distributions in water at various boron concentrations, $\mathrm{pH}$, and temperatures [5].

According these distributions in simple aqueous solution (only hydrogen cations) at low boron concentrations $\mathrm{B}(\mathrm{OH})_{4^{-}}$is the only significant anion, and will be dominant at $\mathrm{pH}>9$ at $100 \mathrm{ppm}$ boron concentration. At higher boron concentrations $\mathrm{B}(\mathrm{OH})_{4^{-}}$will be dominant at higher $\mathrm{pH}$ values $(\mathrm{pH}>10-11)$. At higher boron concentrations (above $1000 \mathrm{ppm}$ ) and intermediate $\mathrm{pH}$ values $(\mathrm{pH}=7-10)$ some polyborates are present too. The amount of polyborates increases with decreasing temperature.

The sorption of boron on strong base ion exchange resin seems to be governed by an oligomer anion formation occurs at an active site during sorption that results in an increase in equilibrium capacity. Lou et al. [6] postulated the following sorption mechanism:

$$
\begin{aligned}
& R-\mathrm{OH}+\mathrm{B}(\mathrm{OH})_{3} \leftrightarrow R-\mathrm{B}(\mathrm{OH})_{4}^{-} \\
& R-\mathrm{B}(\mathrm{OH})_{4}^{-}+2 \mathrm{~B}(\mathrm{OH})_{3} \leftrightarrow R-\mathrm{B}_{3} \mathrm{O}_{3}(\mathrm{OH})_{4}+3 \mathrm{H}_{2} \mathrm{O} \\
& R-\mathrm{B}_{3} \mathrm{O}_{3}(\mathrm{OH})_{4}+2 \mathrm{~B}(\mathrm{OH})_{3} \leftrightarrow R-\mathrm{B}_{5} \mathrm{O}_{6}(\mathrm{OH})_{4}+3 \mathrm{H}_{2} \mathrm{O}
\end{aligned}
$$

where $R$-denotes the ion exchange matrix.

As boron concentration increases in the resin phase, $\mathrm{pH}$ decrease from its peak value $(\mathrm{pH}=9-14)$ polyborates are formed and the total sorption capacity of anion exchanger increases.

It is well known from literature [7-9] that borate could be sorbed by strong base anion exchange columns in hydroxide form. Researches [10] described that the amount of sorbent borate is increasing with feed concentration 
and decreasing with increasing temperature. The apparent borate capacity of resins could be two-three times higher than their total ion exchange capacity. The increased capacity (apparent capacitiy) could be explained by the fact, that instead of a single $\mathrm{B}(\mathrm{OH})_{4^{-}}$anion, polyborate anions are fixed at one ion exchange site. Additionally, large amount of the sorbed borate could be eluted by simple water stream $[8,11]$. Researchers [12-15] published reviews of boron removal and sorption technologies in detail.

The aim of this study is first to investigate the borate sorption batch processes in strong base anion exchange and mixed bed columns containing cation anion exchangers of equal ion exchange capacities. Secondly the purpose of the present research is to investigate in column experiments the elution effect of water and sulfate solution on strongbase anion exchanger previously saturated with different concentration of boric acid.

\section{Experimental}

\subsection{Batch experiments}

The boric acid employed in this study was $99.99 \%$. Water, highly deionized $(<0.1 \mu \mathrm{S} / \mathrm{cm})$ was used as solvent. In the first experiments Purolite NRW600 strong base anion exchanger in hydroxide form was used in anion exchange experiments, and mixed (equal capacity of Purolite NRW600 strong base anion exchanger in hydroxide and Purolite NRW100 strong acid cation exchanger in hydrogen form) was used in mixed bed ion exchange experiments. The experiments were carried out using the batch method. Batch ion exchange experiments were conducted using $2 \mathrm{~cm}^{3}$ swelled anion or $3.22 \mathrm{~cm}^{3}$ mixed bed exchanger resins with $500 \mathrm{~cm} 3$ boric acid solutions with concentrations $0.1 ; 2 ; 4 ; 6 ; 14 ; 17$ and $45 \mathrm{~g} / \mathrm{dm}^{3}$ in polyethylene flasks. At each concentration 3 parallel samples were contacted. The samples were agitated for $24 \mathrm{~h}$ at $150 \mathrm{rpm}$ in anion exchange experiment at $20,30,40$ and $50^{\circ} \mathrm{C}$, and in mixed bed experiments at 20,40 and $50{ }^{\circ} \mathrm{C}$. Then the resin samples were separated by vacuum filtration and were contacted in polyethylene flasks with $10 \mathrm{~cm}^{3} 1 \mathrm{~mol} / \mathrm{dm}^{3} \mathrm{Na}_{2} \mathrm{SO}_{4}$ solutions for $25 \mathrm{~h}$ at $150 \mathrm{rpm}$ at $25^{\circ} \mathrm{C}$. After separation, the resins with vacuum filtration, the eluted borate content was analyzed by ion chromatography and ICP-OES (Inductively Coupled Plasma - Optical Emission Spectrometry).

\subsection{Column experiments}

In the column experiments high purity sodium-sulfate was used for sulfate elution. Purolite NRW600 strong base anion exchanger in hydroxide and Amberlite IRN78 in hydroxide and chloride form was used in anion exchange column experiments. The glass columns used were $20 \mathrm{~cm}$ length and $1.093 \mathrm{~cm}$ diameter, the cross section was $0.9375 \mathrm{~cm}^{2}$. Columns were surrounded by a jacket through which water from a thermostat was circulated so that the columns were maintained at constant temperature within $\pm 0.20^{\circ} \mathrm{C}$ (Fig. 4.).

The resins described above were packed in the columns and were thoroughly washed with ultrapure water after converting the resins into hydroxide or chloride forms. $3 \mathrm{~cm}^{3}$ of swelled strong-base anion exchange resins were used in hydroxide or chloride forms in each experiments.

In the first column experiments $3 \mathrm{~cm}^{3}$ Purolite NRW600 strong base anion exchange resin in hydroxide form were saturated in the glass column with $5,15,20$ and $40 \mathrm{~g} / \mathrm{dm}^{3}$ boric acid solution in excess (11 $\mathrm{g}$ boric acid $280-3700 \mathrm{~cm}^{3}$ solution) at $25{ }^{\circ} \mathrm{C}$. The saturated with borate resin were first treated by vacuum for the liquid removal and then eluted with $200 \mathrm{~cm}^{3}$ salt free water with $5 \mathrm{~cm}^{3} / \mathrm{min}$ flow rate at temperature $250{ }^{\circ} \mathrm{C}$. The effluent $\mathrm{pH}$ and specific conductivity were measured. The effluent was collected and analyzed for borate content by titrimetric method. The remaining solution from resin bed eluted by water was removed by vacuum and then eluted by $200 \mathrm{~cm}^{3} 1 \mathrm{~mol} / \mathrm{dm}^{3}$ sodium-sulfate solution with $5 \mathrm{~cm}^{3} / \mathrm{min}$ flow rate at $25^{\circ} \mathrm{C}$. The effluent $\mathrm{pH}$ and specific conductivity were again measured. The effluent was again collected and analyzed for boric acid content with titrimetric method.

In the next step we investigated the effect of ionic form of anion exchanger in column saturation and elution experiments. We investigated the borate sorption capacity and elution of strong base anion exchanger Amberlite IRN78 in hydroxide and chloride forms. $3 \mathrm{~cm}^{3}$ Amberlite IRN78 strong base anion exchange resin either in hydroxide or chloride form were saturated in a glass column with $3,5,15,20$ and $40 \mathrm{~g} / \mathrm{dm}^{3}$ boric acid solution in excess (11 $\mathrm{g}$

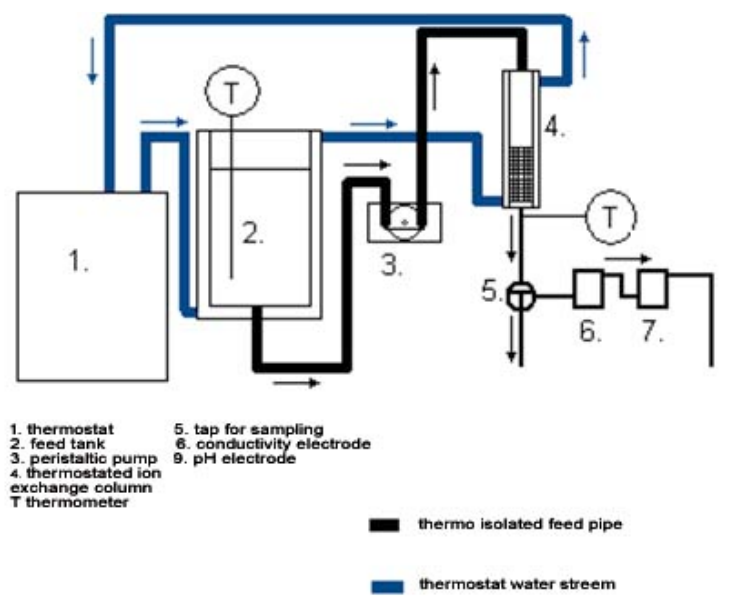

Fig. 4 Scheme of column experiments 
boric acid $280-3700 \mathrm{~cm}^{3}$ solution) at $25{ }^{\circ} \mathrm{C}$. The saturated with borate resin were first treated by vacuum for the liquid removal from the bed and then eluted with $200 \mathrm{~cm}^{3}$ salt free water with $5 \mathrm{~cm}^{3} / \mathrm{min}$ flow rate at $25{ }^{\circ} \mathrm{C}$. The effluent $\mathrm{pH}$ and specific conductivity were measured. The effluent was collected and analyzed for borate content by titrimetric method. The remaining solution from resin was removed from the bed by vacuum and then eluted by $200 \mathrm{~cm}^{3}$ $1 \mathrm{~mol} / \mathrm{dm}^{3}$ sodium-sulfate solution with $5 \mathrm{~cm}^{3} / \mathrm{min}$ flow rate at $25{ }^{\circ} \mathrm{C}$. The effluent $\mathrm{pH}$ and specific conductivity were measured. The effluent was again collected and analyzed for borate content with titrimetric method.

\section{Results and discussion}

\subsection{Batch experiments}

The experimental conditions are listed in Table 1.

Using the fixed, then eluted amount of borate we calculated and expressed the apparent sorption capacity as percentages of the total anion exchange capacity $\left(1.1 \mathrm{meq} / \mathrm{cm}^{3}\right.$ for NRW600). The sorbed borate in total exchange capacity percent are shown in Tables 2-3 and Figs. 5 and 6.

\begin{tabular}{lccccccc}
\multicolumn{3}{c}{ Table 1 Experimental conditions } \\
\hline Resin type & \multicolumn{3}{c}{$\begin{array}{c}\text { Anion exchanger Purolite } \\
\text { NRW600 }\end{array}$} & \multicolumn{3}{c}{$\begin{array}{c}\text { Mixed bed } \\
\text { Purolite NRW100 + } \\
\text { NRW600 }\end{array}$} \\
\hline Temp. $\left({ }^{\circ} \mathrm{C}\right)$ & 20 & 30 & 40 & 50 & 20 & 40 & 50 \\
& 0.1 & 0.1 & 0.1 & 0.1 & 0.1 & 0.1 & 0.1 \\
& 2 & 2 & 2 & 2 & 2 & 2 & 2 \\
& 4 & 4 & 4 & 4 & 4 & 4 & 4 \\
boric acid & 6 & 6 & 6 & 6 & 6 & 6 & 6 \\
concentra-tion & 14 & 14 & 14 & 14 & 14 & 14 & 14 \\
& 17 & 17 & 17 & 17 & 17 & 17 & 17 \\
& 45 & 45 & 45 & 45 & 45 & 45 & 45 \\
\hline
\end{tabular}

Table 2 Apparent borate sorption capacity of NRW600 anion exchange resin in percent of total ion exchange capacity

\begin{tabular}{lcccc}
\hline & \multicolumn{4}{c}{ Temperatures } \\
$\begin{array}{l}\text { boric acid } \\
\text { concentration }\end{array}$ & $20^{\circ} \mathrm{C}$ & $30^{\circ} \mathrm{C}$ & $40^{\circ} \mathrm{C}$ & $50^{\circ} \mathrm{C}$ \\
$\mathrm{g} / \mathrm{dm}^{3}$ & Capacity (\%) & Capacity $(\%)$ & Capacity (\%) & Capacity (\%) \\
& $\%$ & $\%$ & $\%$ & $\%$ \\
\hline 0.1 & 0.7 & 0.9 & 1.0 & 0.7 \\
2 & 11.29 & 12.8 & 10.7 & 8.3 \\
4 & 25.8 & 22.6 & 21.2 & 19.3 \\
6 & 49.4 & 33.8 & 32.7 & 25.3 \\
14 & 129.7 & 119.9 & 108.0 & 105.7 \\
17 & 172.8 & 153.3 & 145.9 & 141.2 \\
45 & 318.6 & 317.9 & 309 & 308.9 \\
\hline
\end{tabular}

Table 3 Apparent borate sorption capacity of mixed bed of equal capacity of NRW600 anion exchange and NRW100 cation exchange resin in percent of total ion exchange capacity

\begin{tabular}{lccc}
\hline & \multicolumn{3}{c}{ Temperatures } \\
$\begin{array}{l}\text { boric acid } \\
\text { concentration } \\
\mathrm{g} / \mathrm{dm}^{3}\end{array}$ & $20^{\circ} \mathrm{C}$ & $40^{\circ} \mathrm{C}$ & $50^{\circ} \mathrm{C}$ \\
& Capacity (\%) & Capacity (\%) & Capacity (\%) \\
\hline 0.1 & 0.6 & $\%$ & $\%$ \\
2 & 9.0 & 0.6 & 0.4 \\
4 & 18.4 & 7.8 & 7.9 \\
6 & 33.3 & 16.0 & 16.0 \\
14 & 111.1 & 28.2 & 27.7 \\
17 & 141.6 & 92.3 & 90.7 \\
45 & 281.8 & 273.5 & 116.8 \\
\hline
\end{tabular}

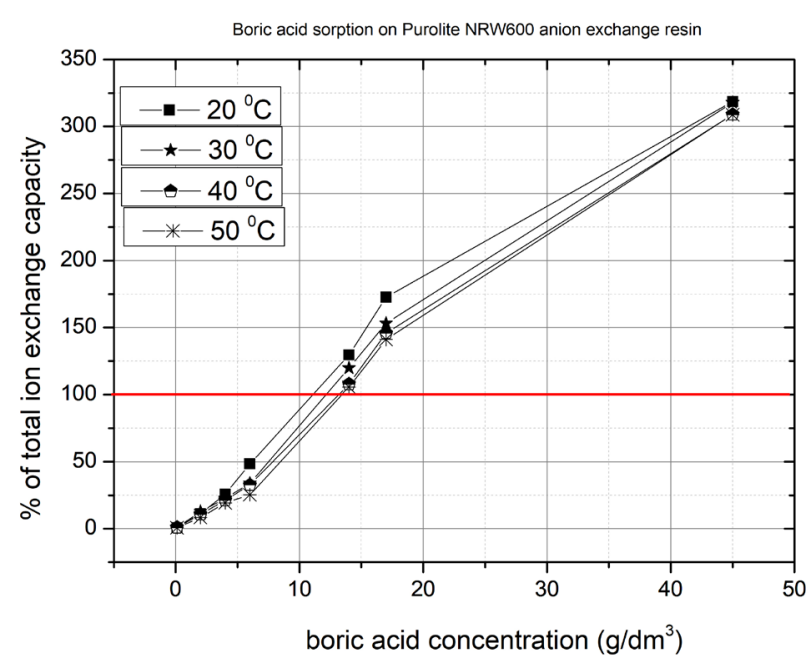

Fig. 5 Borate sorption capacity of Purolite NRW600 anion exchanger

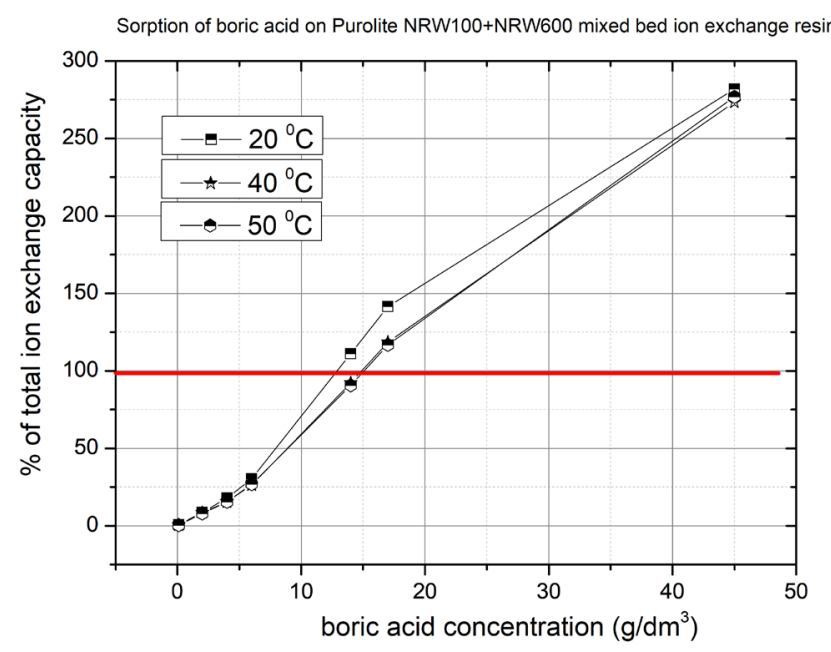

Fig. 6 Borate sorption capacity of mixed bed Purolite NRW100+NRW600 exchanger 


\subsection{Column experiment}

\subsubsection{Experiments with NRW600-OH}

The amount of borate eluted from saturated NRW600-OH column by water increased with the saturation concentration of boric acid (Table 4, Fig. 7).

Table 4 Apparent borate sorption capacity of NRW600-OH anion exchange resin in percent of total ion exchange capacity at $25^{\circ} \mathrm{C}$

\begin{tabular}{lccc}
\hline \multicolumn{3}{c}{ elution by water } \\
\hline $\begin{array}{l}\text { boric acid } \\
\text { concentration } \\
\left(\mathrm{g} / \mathrm{dm}^{3}\right)\end{array}$ & $\begin{array}{c}\text { eluted borate } \\
\left(\mathrm{mg} / 3 \mathrm{~cm}^{3}\right. \\
\text { resin) }\end{array}$ & $\begin{array}{c}\text { eluted borate } \\
\left(\mathrm{meq} / \mathrm{cm}^{3} \text { resin) }\right)\end{array}$ & $\begin{array}{c}\text { eluted borate } \\
(\% \text { of total ion } \\
\text { exchange capacity })\end{array}$ \\
5 & 205 & 1.11 & $100.46 \%$ \\
15 & 335 & 1.81 & $164.16 \%$ \\
20 & 367.5 & 1.98 & $182.13 \%$ \\
40 & 452.5 & 2.44 & $221.76 \%$ \\
\hline
\end{tabular}

following elution by $1 \mathrm{M}$ sodium sulfate solution

\begin{tabular}{lccc}
\hline $\begin{array}{l}\text { boric acid } \\
\text { concentration } \\
\left(\mathrm{g} / \mathrm{dm}^{3}\right)\end{array}$ & $\begin{array}{c}\text { eluted borate } \\
\left(\mathrm{mg} / 3 \mathrm{~cm}^{3}\right. \\
\text { resin) }\end{array}$ & $\begin{array}{c}\text { eluted borate } \\
\left(\mathrm{meq} / \mathrm{cm}^{3} \text { resin) }\right)\end{array}$ & $\begin{array}{c}\text { eluted borate } \\
\text { (\% of total ion } \\
\text { exchange capacity) }\end{array}$ \\
15 & 167.5 & 0.90 & $82.09 \%$ \\
20 & 185 & 1.00 & $90.66 \%$ \\
40 & 195 & 1.05 & $95.56 \%$ \\
\hline & 217.5 & 1.17 & $106.59 \%$ \\
\hline boric acid & sum of elution by water and sodium sulfate solution \\
concentration & $\begin{array}{c}\text { eluted borate } \\
\left(\mathrm{g} / \mathrm{dm}^{3}\right)\end{array}$ & sum of eluted & sum of eluted \\
& resin) & borate & borate \\
5 & 372.5 & 2.01 & of total ion \\
15 & 520 & 2.80 & $182.55 \%$ \\
20 & 562.5 & 3.03 & $254.82 \%$ \\
40 & 670 & 3.60 & $277.69 \%$ \\
\hline
\end{tabular}

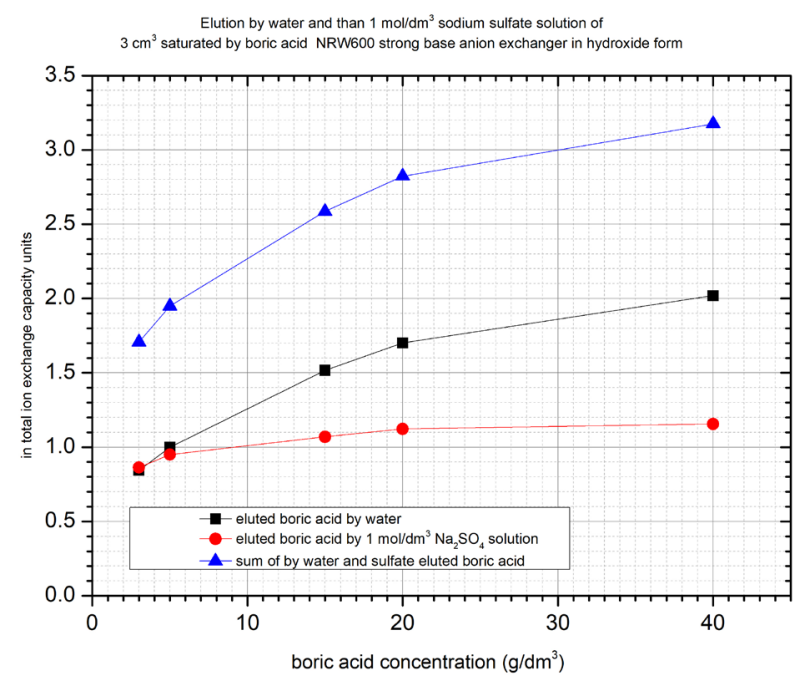

Fig. 7 Elution by water then by $1 \mathrm{M}$ sodium sulfate solution of $3 \mathrm{~cm} 3$ saturated by different concentration boric acid NRW600-OH strong base anion exchanger at $25^{\circ} \mathrm{C}$
At $5 \mathrm{~g} / \mathrm{dm}^{3}$ boric acid saturation concentration the eluted by water borate was nearly equal with $100 \%$ of total ion exchange capacity of resin $\left(1.1 \mathrm{meq} / \mathrm{cm}^{3}\right)$, and the eluted amount increased to $221.76 \%$ of total ion exchange capacity at $40 \mathrm{~g} / \mathrm{dm}^{3}$.

The eluted by sodium-sulfate solution residual borate after elution by water was lower, it changes in 5-40 g/ $\mathrm{dm}^{3}$ saturation concentration between $82-107 \%$ of total ion exchange capacity. The sum of eluted by water and sodium-sulfate solution changed between $182-328 \%$ of total ion exchange capacity. We concluded that water elutes nearly the excess of sorbed borate above its total ion exchange capacity, while the remaining in resin nearly one total ion exchange capacity borate could be eluted by sodium-sulfate solution.

\subsubsection{Experiments with IRN-78OH/Cl}

In case of hydroxide form of IRN78 anion exchange resin the saturation and elution by water and sodium sulfate solution results were similar than in case of NRW600 resin experiments. Results are shown in Table 5 and Fig. 8. Borate eluted by water was equivalent to $84-202 \%$ of total ion exchange capacity $\left(1.2 \mathrm{meq} / \mathrm{cm}^{3}\right)$. Following sodium-sulfate elution washed down additional $86-116 \%$ of total ion exchange capacity.

In case of chloride form the saturation by borate and elution by water and sodium sulfate solution, the results were totally different form the hydroxide form results (Table 6 and Fig. 9).

\section{Conclusions}

\subsection{Batch experiments}

Tables and figures show that the amount of removed borate from aquaeous solution by batch anion exchange with NRW600-OH increased with increasing boric acid concentration. Above $11-13 \mathrm{~g} / \mathrm{dm}^{3}$ boric acid concentration apparent sorption capacity was higher than the total ion exchange capacity of anion exchange resin. Depending on temperature the apparent capacity reached 310-320\% of the total ion exchange capacity. This increased capacity effect could be explained by sorption of borate as borate oligomers. The sorption capacity decreased with increasing temperature. In the mixed bed (equal capacity of NRW100-H cation and NRW600-OH anion exchange resins) batch sorption experiments the capacity of anion exchanger component were the same as in the simple anion exchange experiments, and the capacity of cationic and anionic exhangers were equal. Despite of this fact the 
Table 5 Apparent borate sorption capacity of IRN78 anion-OH exchange resin in percent of total ion exchange capacity at $25^{\circ} \mathrm{C}$

\begin{tabular}{|c|c|c|c|}
\hline & \multicolumn{3}{|c|}{ elution by water } \\
\hline $\begin{array}{l}\text { boric acid } \\
\text { concentration } \\
\left(\mathrm{g} / \mathrm{dm}^{3}\right)\end{array}$ & $\begin{array}{l}\text { eluted borate } \\
\left(\mathrm{mg} / 3 \mathrm{~cm}^{3}\right. \\
\text { resin) }\end{array}$ & $\begin{array}{l}\text { eluted borate } \\
\text { (meq/cm } \mathrm{cm}^{3} \text { resin) }\end{array}$ & $\begin{array}{c}\text { eluted borate } \\
\text { (\% of total ion } \\
\text { exchange capacity) }\end{array}$ \\
\hline 3 & 187.5 & 1.01 & $84.32 \%$ \\
\hline 5 & 222.5 & 1.20 & $99.96 \%$ \\
\hline 15 & 337.5 & 1.82 & $151.62 \%$ \\
\hline 20 & 377.5 & 2.04 & $169.58 \%$ \\
\hline \multirow[t]{2}{*}{40} & 450 & 2.43 & $202.20 \%$ \\
\hline & \multicolumn{3}{|c|}{ following elution by sodium sulfate solution } \\
\hline $\begin{array}{l}\text { boric acid } \\
\text { concentration } \\
\left(\mathrm{g} / \mathrm{dm}^{3}\right)\end{array}$ & $\begin{array}{l}\text { eluted borate } \\
\left(\mathrm{mg} / 3 \mathrm{~cm}^{3}\right. \\
\text { resin) }\end{array}$ & $\begin{array}{l}\text { eluted borate } \\
\text { (meq/cm } \mathrm{cm}^{3} \text { resin) }\end{array}$ & $\begin{array}{c}\text { eluted borate } \\
\text { (\% of total ion } \\
\text { exchange capacity) }\end{array}$ \\
\hline 3 & 192.5 & 1.04 & $86.47 \%$ \\
\hline 5 & 212.5 & 1.15 & $95.47 \%$ \\
\hline 15 & 237.5 & 1.300 & $106.70 \%$ \\
\hline 20 & 250.0 & 1.35 & $112.31 \%$ \\
\hline \multirow[t]{2}{*}{40} & 257.5 & 1.39 & $115.46 \%$ \\
\hline & \multicolumn{3}{|c|}{ sum of elution by water and sodium sulfate solution } \\
\hline $\begin{array}{l}\text { boric acid } \\
\text { concentration } \\
\left(\mathrm{g} / \mathrm{dm}^{3}\right)\end{array}$ & $\begin{array}{l}\text { sum of } \\
\text { eluted borate } \\
\left(\mathrm{mg} / 3 \mathrm{~cm}^{3}\right. \\
\text { resin) }\end{array}$ & $\begin{array}{c}\text { sum of eluted } \\
\text { borate } \\
\text { (meq } / \mathrm{cm}^{3} \text { resin) }\end{array}$ & $\begin{array}{c}\text { sum of eluted } \\
\text { borate } \\
\text { (\% of total ion } \\
\text { exchange capacity) }\end{array}$ \\
\hline 3 & 380 & 2.05 & $170.79 \%$ \\
\hline 5 & 435 & 2.35 & $195.43 \%$ \\
\hline 15 & 575 & 3.10 & $258.32 \%$ \\
\hline 20 & 627.5 & 3.38 & $281.89 \%$ \\
\hline 40 & 707.5 & 3.81 & $317.66 \%$ \\
\hline
\end{tabular}

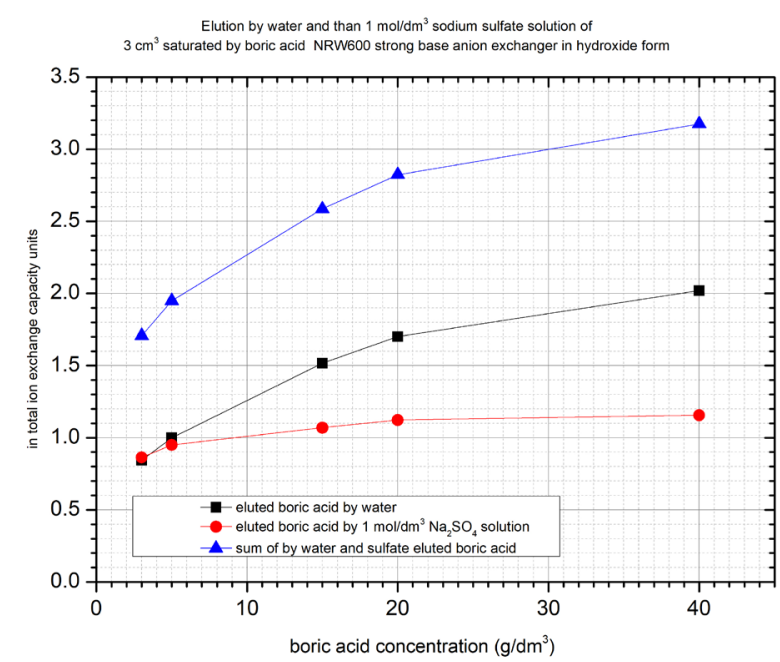

Fig. 8 Elution by water than by sodium sulfate solution of $3 \mathrm{~cm}^{3}$ saturated by borate IRN78-OH strong base anion exchanger at $25^{\circ} \mathrm{C}$

borate sorption capacity of mixed bed was lower maximum by $32-37 \%$. This effect could be explained by the different $\mathrm{pH}$ values in pure anionic and mixed bed resin bed.
Table 6 Apparent borate sorption capacity of IRN78 anion-Cl exchange resin in percent of total ion exchange capacity at $25^{\circ} \mathrm{C}$

\begin{tabular}{|c|c|c|c|}
\hline & \multicolumn{3}{|c|}{ elution by water } \\
\hline $\begin{array}{l}\text { boric acid } \\
\text { concentration } \\
\left(\mathrm{g} / \mathrm{dm}^{3}\right)\end{array}$ & $\begin{array}{l}\text { eluted borate } \\
\left(\mathrm{mg} / 3 \mathrm{~cm}^{3}\right. \\
\text { resin) }\end{array}$ & $\begin{array}{c}\text { eluted borate } \\
\left(\mathrm{meq} / \mathrm{cm}^{3} \text { resin) }\right.\end{array}$ & $\begin{array}{c}\text { eluted borate } \\
\text { (\% of total ion } \\
\text { exchange capacity) }\end{array}$ \\
\hline 5 & 16.3 & 0.09 & $7.25 \%$ \\
\hline 20 & 62.1 & 0.33 & $27.90 \%$ \\
\hline \multirow[t]{2}{*}{40} & 115.3 & 0.62 & $51.75 \%$ \\
\hline & \multicolumn{3}{|c|}{ following elution by sodium sulfate solution } \\
\hline $\begin{array}{l}\text { boric acid } \\
\text { concentration } \\
\left(\mathrm{g} / \mathrm{dm}^{3}\right)\end{array}$ & $\begin{array}{l}\text { eluted borate } \\
\left(\mathrm{mg} / 3 \mathrm{~cm}^{3}\right. \\
\text { resin) }\end{array}$ & $\begin{array}{c}\text { eluted borate } \\
\text { (meq } / \mathrm{cm}^{3} \text { resin) }\end{array}$ & $\begin{array}{c}\text { eluted borate } \\
\text { (\% of total ion } \\
\text { exchange capacity) }\end{array}$ \\
\hline 5 & 4.4 & 0.02 & $1.97 \%$ \\
\hline 20 & 8.9 & 0.05 & $4.00 \%$ \\
\hline 40 & 7.4 & 0.04 & $3.32 \%$ \\
\hline
\end{tabular}

\begin{tabular}{lccc}
\hline \multicolumn{3}{c}{ sum of elution by water and sodium sulfate solution } \\
\hline $\begin{array}{l}\text { boric acid } \\
\text { concentration } \\
\left(\mathrm{g} / \mathrm{dm}^{3}\right)\end{array}$ & $\begin{array}{c}\text { sum of } \\
\text { eluted borate } \\
\left(\mathrm{mg} / 3 \mathrm{~cm}^{3}\right. \\
\text { resin) }\end{array}$ & $\begin{array}{c}\text { sum of eluted } \\
\text { borate } \\
\left(\mathrm{meq} / \mathrm{cm}^{3} \text { resin) }\right.\end{array}$ & $\begin{array}{c}\text { sum of eluted } \\
\text { borate } \\
(\% \text { of total ion } \\
\text { exchange capacity) }\end{array}$ \\
5 & 20.7 & 0.11 & $9.22 \%$ \\
20 & 71.0 & 0.34 & $31.90 \%$ \\
40 & 122.7 & 0.66 & $55.07 \%$ \\
\hline
\end{tabular}

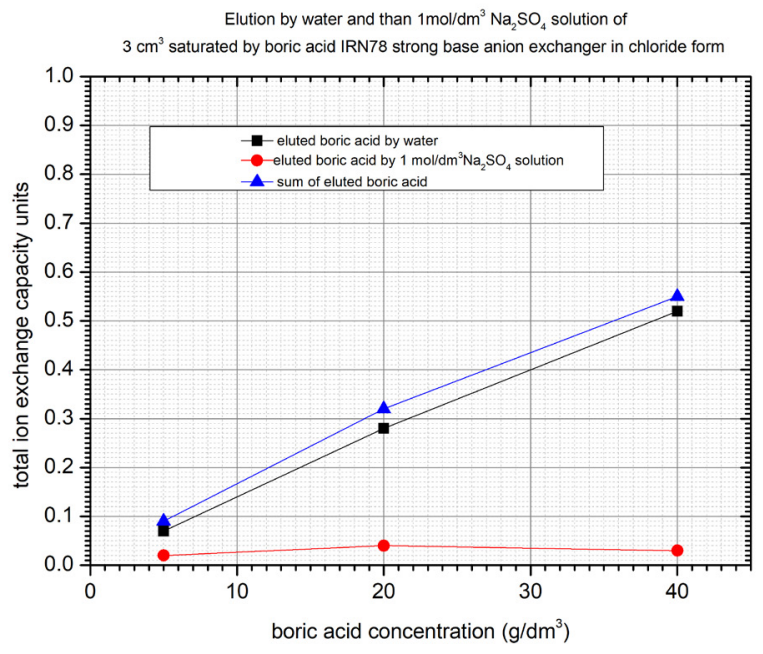

Fig. 9 Elution by water than by sodium sulfate solution of $3 \mathrm{~cm}^{3}$ saturated by borate IRN78-Cl strong base anion exchanger at $25^{\circ} \mathrm{C}$

\subsection{Column experiments}

In case of hydroxide form of IRN78-OH anion exchange resin in column the saturation and elution by water and sodium sulfate solution results were similar than in case of NRW600 resin batch and column experiments. Water eluted borate was equivalent to $84-202 \%$ of total ion exchange capacity $\left(1.2 \mathrm{meq} / \mathrm{cm}^{3}\right)$. Following sodium-sulfate elution washed down additional $86-116 \%$ of total ion exchange capacity. 
The saturated in column by 5,20 and $40 \mathrm{~g} / \mathrm{dm}^{3}$ concentration boric acid solution of IRN78 anion exchange resin in chloride form samples eluted by water and then by sodium sulfate solution released much less borate. Eluted by water borate in this case was equivalent to $7-52 \%$ of total ion exchange capacity and the following sodium-sulfate elution washed down very small amount (2-4\% of total ion exchange capacity). According to literature borate and polyborate sorption needs hydroxide ions in

\section{References}

[1] Parsaeil, M., Goodarzi, M. S., Nasef, M. M. "Adsorption Study for Removal of Boron Using Ion Exchange Resin in Bach System", In: 2011 2nd International Conference on Environmental Science and Technology IPCBEE, Singapore, 2011, pp. 398-402.

[2] Lips, M. "Water Chemistry in Pressurized Water Reactors - A Gösgen-Specific Overview", CHIMIA International Journal for Chemistry, 59(12), pp. 929-937, 2005. https://doi.org/10.2533/000942905777675372

[3] Mesmer, R. E., Baes, Jr., C. F., Sweeton, F. H. "Acidity measurements at elevated temperatures. VI. Boric acid equilibriums", Inorganic Chemistry, 11(3), pp. 537-543, 1972. https://doi.org/10.1021/ic50109a023

[4] Mesmer, R. E., Baes, Jr., C. F., Sweeton, F. H. "Boric acid equilibria and pH in PWR coolants", In: Proceedings of the 32nd International Water Conference, Pittsburgh, PA, USA, 1972, pp. 55-62.

[5] Lou, J. "Modeling of Boron Sorption Equilibrium and Kinetic Studies of Ion Exchange with Boron Solution", PhD Thesis, Graduate College of the Oklahoma State University, 1997. [online] Available at: https://hdl.handle.net/11244/33299 [Accessed: 21 June 2019]

[6] Lou, J., Foutch, G. L., Na, J. W. "Kinetics of boron sorption and Desorption in Boron Thermal Regeneration System", Separation Science and Technology, 35(14), pp. 2259-2277, 2007. https://doi.org/10.1081/SS-100102101

[7] Lee, J., Hussey, D. F., Foutch, G. L. "Ion Exchange modeling of Borates for Ultrapure Water Applications", In: Greig, J. A. (ed.) Ion exchange at the millennium: proceedings of IEX 2000, SCI by Imperial College Press, River Edge, NJ, USA, 2000, pp. 61-68.

[8] Thomson, J., Reents, A. C. "Ion Exchange Processes for Nuclear Power Plants", Industrial and Engineering Chemistry, 51(10), pp. 1269-1261, 1959. https://doi.org/10.1021/ie50598a027 resin phase. We suppose that the resin in chloride form fixes some amount of borate only by physical adsorption or a small quantity by ion exchange as $\mathrm{B}(\mathrm{OH})_{4^{-}}$, and this amount could be eluted by water.

\section{Acknowledgement}

The research reported in this paper has been supported by the National Research, Development and Innovation Fund (TUDFO/51757/2019-ITM, Thematic Excellence Program).

[9] Na, J. W., Lee, K. J. "Characteristics of Boron Adsorption on Strongbase Anion-exchange Resin", Annals of Nuclear Energy, 20(7), pp. 455-462, 1993. https://doi.org/10.1016/0306-4549(93)90087-6

[10] Demirçivi, P., Nasün-Saygılı, G. "Removal of Boron from Waste Waters by Ion Exchange in Batch Systems", World Academy of Science, Engineering and Technology, 2(11), pp. 325-328, 2008. doi.org/10.5281/zenodo.1076830

[11] Kahihana, H., Kotaka, M., Satoh, S., Nomura, M., Okamoto, M. "Fundamental Studies on the Ion-Exchange Separation of Boron Isotopes", Bulletin of the Chemical Society of Japan, 50(1), pp. 158-163, 1977. https://doi.org/10.1246/bcsj.50.158

[12] Wang, B., Guo, X., Bai, P. "Removal technology of boron dissolved in aqueous solutions - A review", Colloids and Surfaces A: Physicochemical and Engineering Aspects, 444, pp. 338-344, 2014. https://doi.org/10.1016/j.colsurfa.2013.12.049

[13] Guan, Z., Lv, J., Bai, P., Guo, X. "Boron removal from aqueous solutions by adsorption - A review", Desalination, 383, pp. 29-37, 2016. https://doi.org/10.1016/j.desal.2015.12.026

[14] Lou, J., Foutch, G. L., Na, J. W. "The Sorption Capacity of Boron on Anionic-Exchange Resin", Separation Science and Technology, 34(15), pp. 2923-2941, 1999. https://doi.org/10.1081/SS-100100813

[15] Bektaş, T. E., Öztıirk, N. "Boron Removal from Aqueous Solution by Ion-Exchange Resin: Column SorptionElution Studies", presented at International Boron Symposium, Eskişehir, Turkey, Sept. 23-25, 2004. (in Turkish) 